\title{
POLITITIKK

\section{Stormaktpolitikk og økt spenning? Kunsten å skille mellom is og bart i Arktis}

\author{
Andreas Østhagen \\ Fridtjof Nansens institutt og Nordområdesenteret ved Nord universitet, Norge \\ Svein Vigeland Rottem \\ Fridtjof Nansens Institutt, Norge
}

\section{Sammendrag}

Nordområdene har vært på den norske utenrikspolitiske agendaen i 15 år. Mye har endret seg i denne perioden. Det som preger debatten i 2020, er forestillinger om stormaktpolitikk og rivalisering i nord. Samtidig hevdes det fra de arktiske hovedstedene at regionen er preget av samarbeid, og at de arktiske statene har fellesinteresser som giør konflikt lite sannsynlig. Hvordan kan to så ulike oppfatninger om Arktis opptre samtidig? I dette bidraget foretar vi en lagdeling mellom tre ulike nivåer av sikkerhetspolitikk i og om nordområdene og Arktis. Dette tydeliggiør hvordan regionen kan være preget av både samarbeid og rivalisering på samme tid. Samarbeid og rivalsering vektes ulikt avhengig av tid og sted, men de er ikke gjensidig utelukkende.

Nøkkelord: Arktis · Russland · Kina · USA · nivåanalyse

\footnotetext{
^Kontaktinformasjon: Andreas Østhagen, e-post: ao@fni.no

(C2020 Andreas Østhagen og Svein Vigeland Rottem. This is an Open Access article distributed under the terms of the Creative Commons Attribution 4.0 International License (http://creativecommons.org/licenses/by/4.0/), allowing third parties to copy and redistribute the material in any medium or format and to remix, transform, and build upon the material for any purpose, even commercially, provided the original work is properly cited and states its license. Citation: Østhagen, A. E Rottem, S. V. (2020). Stormaktpolitikk og økt spenning? Kunsten à skille mellom is og bart i Arktis. Internasjonal Politikk, 78(4), 466-477. http://dx.doi.org/10.23865/intpol.v78.2379
} 


\section{Introduksjon ${ }^{1}$}

Etter å ha blitt plassert på dagsordenen ved flaggplanting og ressursestimater for over et tiår siden fortsetter Arktis - eller nordområdene i en norsk kontekst ${ }^{2}$ - å lokke forskere og journalister nordover for å beskrive "det neste geopolitiske spillet» (Brutschin \& Schubert, 2016; Brzozowski, 2019; Guo \& Wilson, 2020). Forestillingene om en ressurskrig i nord har derimot mer eller mindre blitt forkastet, gitt det faktum at havretten allerede gir de arktiske statene suverene rettigheter i de fleste av disse områdene (Dodds \& Nuttall, 2016; Tamnes \& Offerdal, 2014a).

I tillegg har utenriksdepartementene i de arktiske statene - Canada, Danmark, Finland, Island, Norge, Russland, Sverige og USA - lagt ettertrykkelig vekt på samarbeid i regionen: «[I] Arktis jobber vi sammen» for å løse problemer (Heininen, Everett, Padrtová \& Reissell, 2020; Lavrov \& Støre, 2010). Samarbeid og fellesinteresser ble også trukket frem i 2011, da den rødgrønne regjeringen la frem den forrige stortingsmeldingen om Norges «viktigste strategiske satsingsområde» (Utenriksdepartementet, 2011).

Mye har endret seg siden den gang. Selv om det aldri ble en ressurskamp i nord, har den stormaktpolitiske interessen for - og spillet om - Arktis tiltatt de seneste årene. Annekteringen av Krim i 2014 gjorde sitt til at pendelen svingte. Russland hadde allerede da store ambisjoner i Arktis, men nå skygger, den internasjonalt spente situasjonen også over regionen. Valget av Trump som president i USA i 2016 har forsterket den hissige retorikken. I tillegg til Russlands vedvarende satsing har Kinas interesser i nord blitt mer uttalt. Frankrikes forsvarsminister omtalete derfor Arktis som «det nye Midtøsten» (French Ministry of Armed Forces, 2019), mens Trump-administrasjonen frykter et strategisk kappløp og advarer mot «et nytt Sør-Kina-hav» i Arktis (US Department of State, 2019).

På tross av at de arktiske landene har et åpenbart ønske om å skjerme regionen fra konflikter i andre deler av verden (Byers, 2017), dukker dermed forestillinger om konflikt og stormaktpolitikk i Arktis stadig opp i media, blant politikere og forskere. Selv politikere i noen av de arktiske landene taler med to tunger: De fremhever

\footnotetext{
${ }^{1}$ Denne artikkelen er del av forskningsprosjektet «Security Politics in the Arctic: Analysis Level, Perceptions and Cooperative Mechanisms» finansiert av Forsvarsdepartementet. Den inngår også i en større studie av geopolitikk og konflikt i nordområdene - «The Geopolitics and Geoeconomics of Maritime Spatial Disputes in the Arctic (GEOSEAS)» - finansiert av Norges Forskningsråd. Vi ønsker å takke Whitney Lackenbauer, Mike Sfraga og Frode Mellemvik for innspill og kommentarer samt for den uvurderlige fagfellevurderingen av en ukjent kollega.

${ }^{2}$ Det gjøres et skille mellom "nordområdene» og "Arktis» her. Nordområdene (ofte betegnet som "High North" på engelsk) har i mange sammenhenger blitt brukt for å angi de umiddelbare områdene i nord som er en del av, eller tilstøtende, Norge. Arktis, derimot, brukes som betegnelse for hele den sirkumpolare regionen, altså hele området nord for Polarsirkelen. Det skal samtidig bemerkes at et slikt skille ikke nødvendigvis er entydig akseptert, da man fra norsk offentlig hold ofte bruker nordområdene og Arktis om hverandre. I denne artikkelen prøver vi konsekvent å omtale de norske delene av Arktis som nordområdene, mens vi bruker Arktis for å betegne hele den sirkumpolare regionen. Se også bidraget fra Pedersen og Skagestad i dette nummeret for mer om dette.
} 
hvordan Arktis er en region preget av samarbeid, samtidig som de kritiserer andre arktiske eller ikke-arktiske staters atferd i regionen og påpeker behovet for økt militært nærvær i nord. Hvorfor er det slik, og hvor nøyaktige er slike beskrivelser?

Et grunnleggende begrep i studier av sikkerhetspolitikk er en såkalt nivåanalyse, først formulert av David Singer på 1960-tallet. Singer (1961, s. 80-82) delte inn i det «internasjonale system» og "nasjonalstaten» for bedre å kunne skille mellom hendelser i internasjonal politikk som foregikk på det ene nivået, men ikke på det andre. Systemnivået er koblet til nyrealismen og Kenneth Waltz (1959, 1979), hvor alle stater er sett på som like enheter i søkenen etter relativ makt. Et søkelys på nasjonalstaten, derimot, handler om å forstå enkeltstaters utenrikspolitiske avgjørelser. Graham Allisons (1969) studie av USAs håndtering av Cubakrisen i 1962 er kanskje det fremste eksemplet på en slik analyse.

De siste 20 årene har vi også sett en rekke regionale studier av sikkerhetspolitikk. Etter at den kalde krigens systemiske maktbalanse på internasjonalt nivå avtok, fikk regionale sikkerhetspolitiske dynamikker i regioner som for eksempel Middelhavet, Sørøst-Asia eller Arktis økt akademisk oppmerksomhet (Buzan, Wæver \& Wilde, 1998; Hoogensen, 2005). Den avgiørende faktoren i slike studier er geografisk nerhet. Stater som befinner seg i nærheten av hverandre, har mer intense interaksjoner (positive og negative) enn de som befinner seg på ulike kontinenter (Kelly, 2007). Dermed holder det ikke å se bare på enkeltstaters utenrikspolitikk eller på det internasjonale systemet, vi må også vurdere samspillet mellom stater innad i geografiske "regioner».

Vi lener oss på disse grovt skisserte analysenivåene for bedre å forstå utviklingen i Arktis og nordområdene. Vi skiller dermed mellom tre nivåer: det internasjonale (systemnivået), det regionale (arktiske) og det nasjonale (norske) nivået (se figur 1). En slik tilnærming bidrar til å få frem de forskjellige dynamikkene som finnes i Arktis. Den forklarer hvorfor ideer om konflikt vedvarer, og hvorfor disse ideene ikke nødvendigvis er i motsetning til ideer om regionalt samarbeid og stabilitet. I tillegg muliggjør en slik lagdeling en diskusjon av hvordan de ulike arktiske statene oppfatter sikkerhetspolitiske utfordringer i sine «nordområder», her med vekt på Norge.

Artikkelen er således et bidrag til den norske nordområdedebatten langs flere akser. Vi følger i rekken av analyser av internasjonal politikk og nordområdene som har kommet i kjølvannet av den norske nordområdesatsingen. ${ }^{3}$ Vi har som formål å videreutvikle og oppdatere måten vi forstår og analyser sikkerhetpolitikk på i Arktis, gitt dagens trender med stormaktpolitikk og økt spenning, ${ }^{4}$ og vi bidrar til å sette regjeringens nordområdemelding i 2020 i kontekst. Der hvor eksisterende faglitteratur har en tendens til å konkludere den ene eller den andre veien om forholdene i Arktis, åpner vi opp for å vise - ved en nivåanalyse - hvordan ulike forhold kan eksistere simultant.

\footnotetext{
${ }^{3}$ Se f.eks. Åtland, 2014; Hønneland \& Rowe, 2010; L. C. Jensen, Ø. Jensen \& Rottem, 2011; Østhagen, 2018; Pedersen, 2018; Sfraga, Wilson Rowe, Sverdrup, Friis \& Hønneland, 2020; Stokke, 1990; Tamnes \& Offerdal, 2014b; Wegge, 2011.

${ }^{4}$ Se Ingeborg Moes (2020) reportasje i Aftenposten om endringene i Arktis de siste årene og den påfølgende maktkampen.
} 


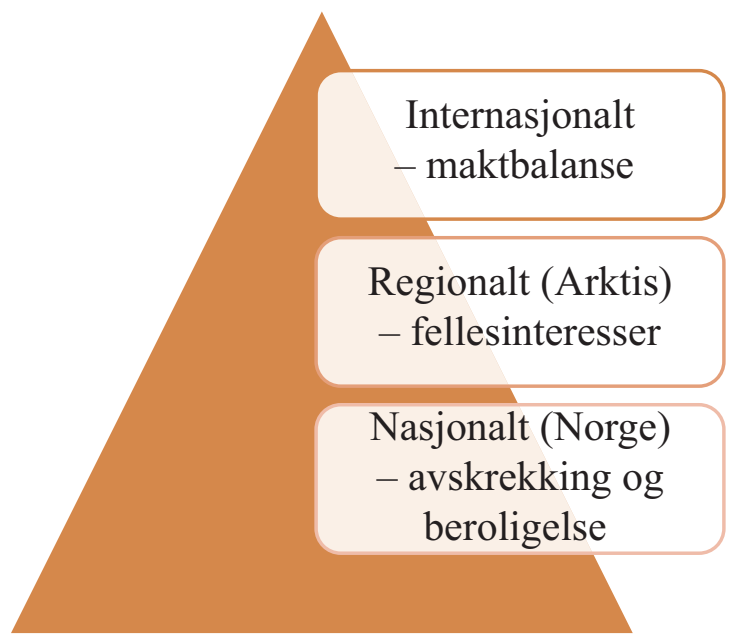

Figur 1 En enkel inndeling i tre nivåer gjør det enklere å skille de ulike dynamikkene i Arktis fra hverandre, og slik også å forstå hvorfor ideen om konflikt vedvarer samtidig som de arktiske statene samarbeider.

Denne artikkelen er inndelt i tre deler, hvor hver del tar for seg de (sikkerhets)politiske dynamikkene på hvert av de nevnte nivåene. Vi starter med det overordnede, altså det internasjonale nivået, før vi ser på de regionale dynamikkene i Arktis og deretter det nasjonale nivåt med hensyn på sikkerhetspolitikk. Gitt plassbegrensninger er det naturligvis ikke mulig å gi en fullstendig fremstilling av alt som skjer på hvert nivå - og hvordan nivåene henger sammen - men vi mener at vår fremstilling er tilstrekkelig for å påvise hvordan ulike samspillseffekter preger forskjellige nivåer. Vi samler opp trådene med noen avsluttende betraktninger.

\section{Det internasjonale nivået: maktbalanse}

Under den kalde krigen hadde Arktis en fremtredende posisjon i den politiske og militære konkurransen mellom to supermakter. Regionen var viktig, ikke på grunn av interessemotsetninger i selve Arktis, men på grunn av dens strategiske rolle i den systemiske konkurransen mellom USA/Nato og USSR på internasjonalt nivå. Norge var ett av bare to Nato-land (det andre var Tyrkia) som delte en landegrense til Sovjetunionen. Og Alaska - om enn atskilt av Beringstredet - var i umiddelbar nærhet til den nordøstlige delen av Russland. Grønland og Island var strategisk plassert i Nord-Atlanteren, og Kolahalvøya var, og er fremdeles, nøkkelen i russisk militærplanlegging ettersom den gir Russland tilgang til Atlanterhavet.

Da den kalde krigen tok slutt, gikk Arktis fra en region med geopolitisk rivalisering til en der Russland kunne bli inkludert i forskjellige samarbeidsordninger med sine tidligere motstandere. Flere regionale organisasjoner (som Arktisk råd, 
Barentsrådet og Den nordlige dimensjon) dukket opp i 1990-årene for å håndtere spørsmål som miljøforringelse, regional og lokal utvikling og grenseoverskridende samarbeid. Selv om samspillet mellom arktiske stater og arktiske folk økte i denne perioden, forsvant regionen likevel fra den geopolitiske radaren og mistet sin systemiske betydning.

Nylig har den strategiske betydningen av den arktiske regionen økt. Som under den kalde krigen har regionens strategiske betydning utviklet seg, først og fremst fordi Russland er innstilt på å gjenreise sin militære og politiske posisjon globalt. Arktis blir et av de geografiske områdene der dette kan gjøres mer eller mindre uhindret, samtidig som regionen er sentral fordi den russiske Nordflåten, som huser landets strategiske atomubåter, er basert på Kolahalvøya. Russlands økte militære vektlegging av Arktis kommer dermed både på grunn av smeltingen av havisen, som medfører økt skipsfart og aktivitet, og grunnet betydningen av Arktis for Moskvas overordnede strategiske planer og ambisjoner.

I motsetning til det som var tilfellet under den kalde krigen, har også Kina dukket opp som en aktør i nord. Når Beijing hevder sin innflytelse på verdensscenen, er Arktis en av mange regioner der Kinas tilstedeværelse og samhandling er komponenter i en maktutvidelse med både myke og harde vendinger (se Edstrøm, Stensdal \& Heggelund i dette nummeret, og Koivurova \& Kopra, 2020). Kina beskriver seg selv som en "nær-arktisk stat», noe som kan oppfattes som at Beijing ikke bare har en rett til å involvere seg, de har også en plikt (The Guardian, 2019).

Men Kinas inntreden i arktispolitikk skaper reaksjoner, spesielt hos USA. Pompeos advarsel i 2019 om at Beijings arktiske interesser risikerer å skape et «nytt Sør-Kina-hav» i nord, fremhever hvordan USA ser på Arktis som nok en arena der den nye systemiske konkurransen mellom de to landene tiltar (US Department of State, 2019). ${ }^{5}$ Dette er i liten grad koblet til kinesiske handlinger $i$ Arktis, det handler i større grad om at USA under Donald Trump ønsker å stagge Kinas globale fremvekst på så mange områder som mulig.

\section{Det regionale nivået: fellesinteresser}

Det er en viktig forskjell mellom disse overordnede strategiske hensynene og det som angår den arktiske regionen spesielt. Da den kalde krigens systemiske konkurranse tok slutt, blomstret regionalt samspill og samarbeid i nord. Som svar på bekymringene om «mangel på styring» i Arktis, forårsaket av en generelt økende interesse internasjonalt, samlet de fem arktiske kyststatene seg på Grønland i 2008 og erklærte Arktis for å være en region preget av samarbeid (Arctic Ocean Conference, 2008). De bekreftet også sine intensjoner om å jobbe innenfor etablerte internasjonale ordninger og avtaler, da særlig FNs havrettskonvensjon.

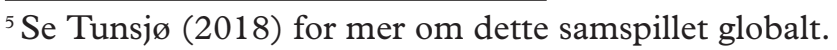


I etterkant av dette møtet har de arktiske statene til stadighet gjentatt mantraet om samarbeid, artikulert i relativt strømlinjeformede arktiske policy- og strategidokumenter (Heininen et al., 2020; Rottem, 2010). Forverringen i forholdet mellom Russland og de andre arktiske statene, som startet i 2014, har ikke endret på dette selv om forholdet sikkerhetspolitisk har blitt mer anstrengt (Byers, 2017; Østhagen, 2016). De møttes på nytt på Grønland i 2018 og gjentok lovnader om samarbeid og vern av havretten (Jacobsen, 2018) - som tross alt gir de arktiske statene suverene rettigheter i store deler av Polhavet (se figur 2).

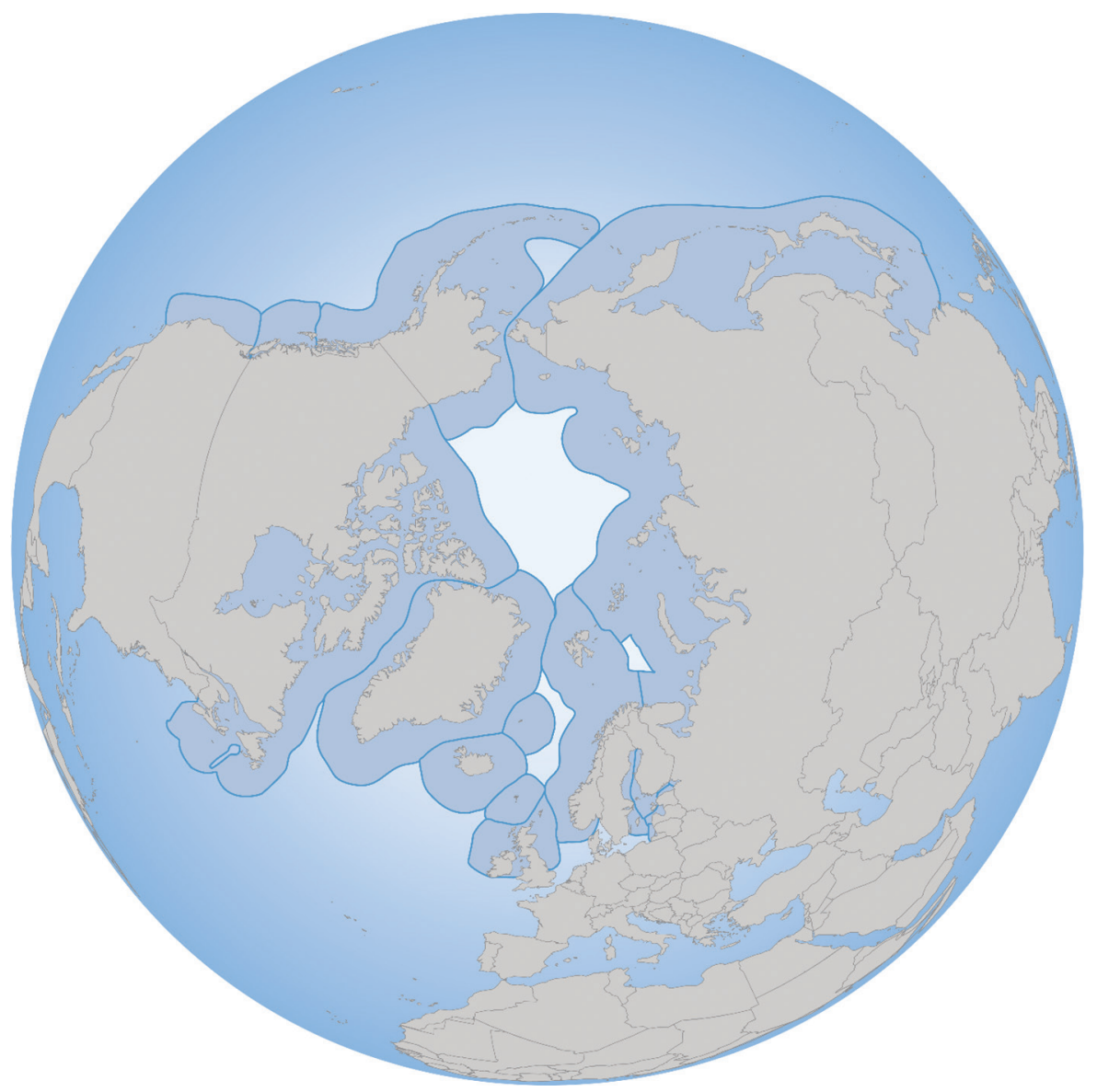

Figur 2 De arktiske kyststatene har mer eller mindre delt regionen mellom seg, med hjemmel i havretten. Dermed er det lite å krangle over når det kommer til ressurser og grenser. Kart: Malte Humpert, The Arctic Institute.

Faktisk har det blitt hevdet at samarbeid på lavt (regionalt) nivå er med på å sikre et lavt spenningsnivå i nord. Fremveksten av Arktisk råd som det primære forumet for regionale saker i Arktis spiller inn i her, på tross av (eller på grunn av) at 
forumet eksplisitt unnlater å diskutere sikkerhetspolitikk (Graczyk \& Rottem, 2020). Et økende antall aktører har derfor søkt rådet om observatørstatus. Disse inkluderer Kina, India, Tyskland og EU. Denne utviklingen tjener de arktiske landene mer enn noen andre, ettersom de sikrer seg at arktiske spørsmål behandles av de arktiske statene selv (Rottem, 2017).

De arktiske statene har vist en preferanse for et stabilt politisk miljø der de opprettholder sin dominans i regionen. Dette anspores ikke bare av regionalt samarbeid, men også av økonomiske interesser som er tjent med et stabilt politisk klima. Som konsekvens av den smeltende isen og høye råvarepriser ved starten av dette århundret har de arktiske statene sett nordover både når det gjelder investeringer og muligheter knyttet til både skipsfart, fiskeri og olje- og gassutvinning. Spesielt Russlands ambisjoner med Nordøstpassasjen og industriell aktivitet på Jamalhalvøya krever tilstedeværelse i nord, men også stabilitet og langsiktighet for å tiltrekke seg vestlige og østlige investorer. ${ }^{6}$

Vi ser dermed et interessefellesskap hos de arktiske statene. Dette er særlig synlig på det regionale nivået i nord, hvor gjensidig avhengighet og fellesinteresser fører til fravær av konflikt. Her er de arktiske statene tjent med å samarbeide, nettopp med mål om å fremme egne interesser. Et slikt samarbeid vil igjen skape en avhengighet mellom aktørene, som igjen vil heve terskelen for å tre ut av samarbeidet (Young, 1986).

\section{Det nasjonale nivået: avskrekking og beroligelse}

I tillegg må vi, for å forstå sikkerhetspolitiske dynamikker i nord, inkludere et nasjonalt perspektiv på utfordringene og mulighetene i Arktis. Sentralt er rollen den nordlige regionen spiller i nasjonale forsvars- og sikkerhetshensyn, ettersom det er stor variasjon i hva hvert land velger å prioritere i sine nordlige områder når det gjelder nasjonal sikkerhet og forsvar.

For Russland er Arktis som nevnt integrert i nasjonale forsvarshensyn. Selv om disse i stor grad er knyttet til utviklingen andre steder, har investeringer i militær infrastruktur i Arktis også en arktisk innvirkning, om enn først og fremst for de landene som ligger nær Russland (i hovedsak Finland, Norge og Sverige). Følgelig er Arktis for Norden også integrert i den nasjonale forsvarspolitikken, nettopp fordi det er her Russland - som stormakt - investerer noe av sin militære kapasitet.

I Nord-Amerika, derimot, har ikke Arktis den samme sentrale rollen i nasjonale sikkerhetshensyn (Østhagen, Sharp \& Hilde, 2018). Kommentatorer i Canada har en tendens til å hevde at de mest umiddelbare bekymringene for de arktiske områdene ikke er forsvarsevne, men de sosiale og helsemessige forholdene i arktiske samfunn (Greaves \& Lackenbauer, 2016). Alaska har en noe mer sentral rolle i USAs

\footnotetext{
${ }^{6}$ Yamal LNG er et av verdens største LNG-prosjekter, hvor russiske Novatek har 50,1 prosent eierskap, franske Total har 20 prosent eierskap, kinesiske CNPC har 20 prosent eierskap, og Silk Road Fund har 9,9 prosent eierskap.
} 
forsvarspolitikk, med grense til den russiske regionen Tsjukotka over Beringstredet, men dette kan ikke sammenlignes med den rollen den russiske grensen har for Norges (og Natos) sikkerhetspolitiske bekymringer. USA har ennå til gode å investere betydelig i kapasiteter og infrastruktur i nord (Conley, Melino, Tsafos \& Williams, 2020), selv om retorikken rundt Arktis har hardnet under Trump-administrasionen.

USAs begrensede engasjement $i$ egne «nordområder» synliggjør de nevnte nyanseforskjellene mellom det internasjonale (system)nivået og nasjonale hensyn. På et systemnivå kan og vil USA engasjere seg i regioner som Arktis når det måtte sammenfalle med amerikanske interesser. Her er øvelsesaktiviteten til USAs sjette flåte i Barentshavet i mai 2020 og økt amerikansk deltakelse i Nato-øvelser i Norge etter 2014 - som Cold Response og Trident Juncture - eksempler på USAs evne og vilje til å engasjere seg sikkerhetspolitisk i deler av Arktis ved behov (se også bidraget til Bjur, Eggen \& Hilde i dette nummeret). Samtidig har Alaska for USA først og fremst fungert som base for et rakettforsvar og et begrenset antall strategiske styrker (Hilde, 2014, s. 149), i motsetning til hva regionen betyr for norsk forsvars- og sikkerhetspolitikk.

Forholdene stater har seg imellom, er derimot ikke enkle å skjære over en kam. Det beste eksemplet på dette er det bilaterale forholdet Norge har til Russland. Sikkerhetspolitisk kan det velbrukte mantraet "avskrekking og beroligelse» fortsatt nyttiggjøres til å oppsummere norsk tilnærming til naboen i øst (Søreide, 2017; se også Børresen, Gjeseth \& Tamnes, 2004). Norge arbeider aktivt for å «avskrekke» Russland ved å opprettholde egen forsvarsevne og engasjere allierte land i våre utfordringer i nord. Samtidig bygges samarbeidsrelasjoner over grensen med Russland, både militært og sivilt, med det formål å bryte ned mistillit og unngå krisesituasjoner (Søreide, 2017; se også Børresen et al., 2004).

Norges utenrikspolitiske beslutninger i nord er naturligvis påvirket av utviklingen på de to andre nivåene allerede beskrevet. Maktbalanse og spenninger mellom USA, Kina og Russland får konsekvenser for norsk politikk overfor de samme aktørene, spesielt sistnevnte. Regionale avtaler og dynamikker innad i den arktiske regionen preger Norges muligheter i den samme regionen. Samtidig er det nasjonale nivået mer komplekst - også utenrikspolitisk - enn at dynamikker på et annet nivå setter hele rammen for norsk handlingsrom. Her kommer lokale og nasjonale interesser i spill, som behov for handel over grensen mellom Finnmark og Murmansk.

Her består åpenbart statenes avveining i utvikling av utenrikspolitikk av mer enn bare maktbalanse og fellesinteresser. Historiske forhold, identitet og effekten av norsk-russisk samarbeid i tre tiår etter Sovjetunionens fall gjør seg gjeldende (L.C. Jensen, 2017). Som Steinveg og Medby påpeker i dette nummeret, er også narrativ viktig for Utenriksdepartementets utvikling av en nordområdepolitikk. Forholdet mellom Norge og Russland i nord, da spesielt knyttet til Barentssamarbeidet og praktiske former for samarbeid, er eksempler på aktivitet på det nasjonale nivået som ikke nødvendigvis er preget av verken en systemisk maktbalanse eller regionale samarbeidsdynamikker (se for eksempel Hoel om fiskeripolitikk i dette nummeret), men som innehar litt av begge deler (L.C. Jensen, 2017). 


\section{Avsluttende betraktninger}

For å oppsummere: På det internasjonale planet har Arktis (herunder nordområdene) igjen klatret på listen over strategiske bekymringer blant gamle og nye stormakter (USA, Russland, Kina). Vi har brukt en enkel inndeling i tre analysenivåer - det internasjonale, det regionale og det nasjonale - for å få frem hvordan ulike dynamikker tar plass på ulike nivår. Dette har bidratt til å få frem hvordan sikkerhetspolitikk i den arktiske regionen ikke kan kokes ned til konflikt eller ingen konflikt.

På et strategisk nivå vil Arktis ikke bli mindre viktig, rett og slett fordi USA og Russland allerede er i regionen, og fordi Kina i økende grad demonstrerer sine (strategiske) nordlige interesser. Jo verre forholdene mellom disse aktørene er globalt, desto mer spenning vil vi sannsynligvis også se i Arktis. Denne spenningen materialiseres ved utfordrende uttalelser, sanksjoner og tidvis militær oppvisning. Dette har lite å giøre med regionale hendelser i Arktis (issmelting, økonomiske muligheter osv.), og har alt å giøre med den strategiske posisjonen som Arktis innehar mellom disse aktørene. Imidlertid har de arktiske statene begrenset, om noen, begrunnelse for å inngå i direkte regional konflikt over ressurser eller territorier i Arktis - selv om lokale rivaliseringer, som den mellom Norge og Russland, vedvarer knyttet til nasjonale interesser.

Arktiske forhold i det 21. århundre har vist seg å være overraskende fredelige, styrt av de arktiske staters ønske om å skjerme de politiske dynamikkene i nord for konsekvensene av konflikter andre steder. Selv om et slikt ønske gjør seg gjeldende på det regionale nivået - for eksempel giennom Ilulissat-erklæringen eller avtaler tilknyttet Arktisk råd - betyr ikke det at andre forhold kan være preget av konflikt og spenning i nord. Naturligvis finner vi tegn på at ulike dynamikker gjør seg gjeldende på hvert av de tre analysenivåene vi har skissert. Men poenget her er at noen dynamikker gjør seg mer gjeldende enn andre, som igjen fordrer at vi evner å skille mellom is og bart når vi skal analysere utviklingen i våre nordområder - og i Arktis for øvrig.

Dette gjør at ideer om konflikt og samarbeid ikke nødvendigvis er gjensidig utelukkende, men komponenter i et mer komplekst bilde av nordområdene og Arktis. Paradoksalt nok kan regionen være preget av konflikt og samarbeid på samme tid. I så måte er ikke regionen i en særstilling sammenliknet med andre regioner. Det er i dette bildet Norge - og en ny stortingsmelding om nordområdene - må finne sin plass.

\section{Om forfatterne}

Andreas Østhagen er seniorforsker ved Fridtjof Nansens institutt i Oslo og arbeider med nordområde-, hav- og sikkerhetspolitikk. Han er også tilknyttet Nordområdesenteret ved Nord Universitet i Bodø. Østhagen har en doktorgrad i internasjonal politikk fra University of British Columbia, en mastergrad europeisk politikk fra 
London School of Economics, og en bachelorgrad i politisk økonomi fra NTNU. Tidligere har Østhagen jobbet som rådgiver ved Nord-Norges Europakontor i Brussel og som forsker ved Institutt for forsvarsstudier i Oslo og Center for Strategic \& International Studies i Washington DC.

Svein Vigeland Rottem er seniorforsker ved Fridtjof Nansen Institutt. Han er også tilknyttet Bjørknes Høyskole. Rottem har doktorgrad i statsvitenskap fra UiT Norges arktiske universitet, hvor han også jobbet med å utvikle en rekke undervisningstilbud til det norske forsvaret. Hans doktorgrad omhandlet det norske forsvarets møte med en ny virkelighet etter den kalde krigen med et særlig blikk på utviklingen i nord. I de seneste år har Rottems forskning særlig vært rettet mot geopolitikk i Arktis, arktiske styringsmekanismer, forholdet mellom politikk og vitenskap og Arktisk råd. Han har publisert en rekke bøker, akademiske artikler og reporter om disse temaene.

\section{Litteraturliste}

Allison, G. T. (1969). Conceptual models and the Cuban missile crisis. American Political Science Review, 63(3), 689-718.

Arctic Ocean Conference. (2008). The Ilulissat declaration. Arctic Ocean Conference. https://www.regjeringen. no/globalassets/upload/ud/080525_arctic_ocean_conference-_outcome.pdf

Åtland, K. (2014). Interstate relations in the Arctic: An emerging security dilemma. Comparative Strategy, 33(2), 145-166.

Brutschin, E. \& Schubert, S. R. (2016). Icy waters, hot tempers, and high stakes: Geopolitics and geoeconomics of the Arctic. Energy Research and Social Science, 16(C), 147-159.

Brzozowski, A. (2019, 26. februar). Fault-lines surface in Arctic as region turns into geopolitical hotspot. EurActiv. https://www.euractiv.com/section/arctic-agenda/news/fault-lines-surface-in-arctic-as-regionturns-into-geopolitical-hot-spot/

Buzan, B., Wæver, O. \& de Wilde, J. (1998). Security: A new framework for analysis. Boulder, CO: Lynne Rienner.

Byers, M. (2017). Crises and international cooperation: An Arctic case study. International Relations, 31(4), 375-402.

Børresen, J., Gjeseth, G. \& Tamnes, R. (2004). Norsk forsvarshistorie bd. 5: allianseforsvar $i$ endring 1970-2000. Eide forlag.

Conley, H. A., Melino, M., Tsafos, N. \& Williams, I. (2020). America's Arctic moment: Great power competition in the Arctic to 2050. https://www.csis.org/analysis/americas-arctic-moment-great-power-competition-arctic2050

Dodds, K. \& Nuttall, M. (2016). The scramble for the poles: The geopolitics of the Arctic and Antarctic. Cambridge, England: Polity Press.

French Ministry of Armed Forces. (2019). France and the new strategic challenges in the Arctic. https://www. defense.gouv.fr/english/layout/set/print/content/download/565142/9742558/version/3/file/France + and $+\mathrm{t}$ he+New+Strategic+Challenges+in+the+Arctic+-+DGRIS_2019.pdf

Graczyk, P. \& Rottem, S. V. (2020). The Arctic Council: Soft actions, hard effects? I G. H. Gjørv, M. Lanteigne \& H. Sam-Aggrey (Red.), Routledge handbook of Arctic security. London, England: Routledge.

Greaves, W. \& Lackenbauer, W. P. (2016, 23. mars). Re-thinking sovereignty and security in the Arctic. OpenCanada. https://www.opencanada.org/features/re-thinking-sovereignty-and-security-arctic/

Guo, L. \& Wilson, S. L. (2020, 29. mars). China, Russia, and Arctic geopolitics. The Diplomat. https:// thediplomat.com/2020/03/china-russia-and-arctic-geopolitics/

Heininen, L., Everett, K., Padrtová, B. \& Reissell, A. (2020). Arctic policies and strategies — analysis, synthesis, and trends. Helsingfors: Ministry for Foreign Affairs of Finland. http://pure.iiasa.ac.at/id/eprint/16175/1/ ArticReport_WEB_new.pdf

Hilde, P. S. (2014). Armed forces and security challenges in the Arctic. I R. Tamnes \& K. Offerdal (Red.), Geopolitics and security in the Arctic: Regional dynamics in a global world (s. 147-165). London, England: Routledge. 


\section{Andreas Østhagen og Svein Vigeland Rottem}

Hoogensen, G. (2005). Bottoms up! A toast to regional security? International Studies Review, 7(2), $269-274$.

Hønneland, G. \& Rowe, L. (2010). Nordområdene - hva nå? Trondheim: Tapir Akademisk Forlag.

Jacobsen, M. (2018, 23. mai). Ilulissat declaration's 10-year anniversary. High North News. https://www. highnorthnews.com/en/ilulissat-declarations-10-year-anniversary

Jensen, L. C. (2017). An Arctic "marriage of inconvenience»: Norway and the othering of Russia. Polar Geography, 40(2), 121-143.

Jensen, L. C., Jensen, Ø. \& Rottem, S. V. (2011). Norwegian foreign policy in the High North: Energy, international law and security. Atlantisch Perspectief, 35(3), 1-7.

Kelly, R. E. (2007). Security theory in the «new regionalism». International Studies Review, 9(2), 197-229.

Koivurova, T. \& Kopra, S. (Red.). (2020). Chinese policy and presence in the Arctic. Leiden: Brill Nijhoff.

Lavrov, S. \& Støre, J. G. (2010, 21. september). Canada, take note: Here's how to resolve maritime disputes. The Globe and Mail. http:/www.theglobeandmail.com/opinion/canada-take-note-heres-how-to-resolvemaritime-disputes/article4326372

Moe, I. (2020, 22. februar). Arktis smelter. Slik bidrar det til maktkamp på Norges dørstokk. Aftenposten. https://www.aftenposten.no/verden/i/awBvA5/arktis-smelter-slik-bidrar-det-til-maktkamp-paa-norgesdoerstokk

Pedersen, T. (2018). Når nordområdene lever sitt eget liv. Internasjonal Politikk, 76(3), 140-158.

Rottem, S. V. (2010). Klima og sikkerhet i Arktis. Internasjonal Politikk, 68(2), 183-204.

Rottem, S. V. (2017). The Arctic Council: Challenges and recommendations. I S. V. Rottem \& I. F. Soltvedt (Red.), Arctic governance: Law and politics. (Bd. 1, s. 231-251). London, England: I.B. Tauris.

Sfraga, M., Wilson Rowe, E., Sverdrup, U., Friis, K. \& Hønneland, G. (2020). A governance and risk inventory for a changing Arctic. Background paper for the Arctic security roundtable at the Munich security conference 2020. https://www.wilsoncenter.org/publication/governance-and-risk-inventory-changing-arctic

Singer, J. D. (1961). The level-of-analysis problem in international relations. World Politics, 14(1), 77-92.

Stokke, O. S. (1990). The northern environment: Is cooperation coming? Annals of the American Academy of Political and Social Science, 512(1), 58-68.

Søreide, I. E. (2017). En balansert sikkerhetspolitikk. Hentet fra. https://www.regjeringen.no/no/aktuelt/ avskrekkingberoligelse/id2536988/

Tamnes, R. \& Offerdal, K. (2014a). Conclusion. I R. Tamnes \& K. Offerdal (Red.), Geopolitics and security in the Arctic: Regional dynamics in a global world (s. 166-177). Routledge.

Tamnes, R. \& Offerdal, K. (Red.). (2014b). Geopolitics and security in the Arctic: Regional dynamics in a global world. Routledge.

The Guardian. (2019, 6. mai). US warns Beijing's Arctic activity risks creating "new South China Sea». The Guardian. https:/www.theguardian.com/world/2019/may/06/pompeo-arctic-activity-new-south-china-sea

Tunsjø, Ø. (2018). The return of bipolarity in world politics: China, the United States, and geostructural realism. New York: Columbia University Press.

US Department of State. (2019). Looking north: Sharpening America's Arctic focus. Remarks. https://www. state.gov/looking-north-sharpening-americas-arctic-focus/

Utenriksdepartementet. (2011). Nordområdene: Visjon og virkemidler (Meld. St. 7 (2011-2012)). Hentet fra https:/www.regjeringen.no/contentassets/a0140460a8d04e4ba9c4af449b5fa06d/no/pdfs/stm2011201 20007000 dddpdfs.pdf

Waltz, K. N. (1959). Man, the state, and war. New York: Columbia University Press.

Waltz, K. N. (1979). Theory of international politics. New York: McGraw-Hill.

Wegge, N. (2011). Small state, maritime great power? Norway's strategies for influencing the maritime policy of the European Union. Marine Policy, 35(3), 335-342.

Young, O. R. (1986). International regimes: Toward a new theory of institutions. World Politics, 39(1), $104-122$.

Østhagen, A. (2016). High north, low politics. Maritime cooperation with Russia in the Arctic. Arctic Review on Law and Politics, 7(1), 83-100.

Østhagen, A. (2018). Geopolitics and security in the Arctic. I M. Nuttall, T. R. Christensen \& M. Siegert (Red.), Routledge handbook of the polar regions (s. 348-356). Abingdon, England: Routledge.

Østhagen, A., Sharp, G. L. \& Hilde, P. S. (2018). At opposite poles: Canada's and Norway's approaches to security in the Arctic. Polar fournal, 8(1), 163-181. 


\section{Abstract in English \\ Great Power Politics and Increased Tension? \\ The Art of Differentiating Analyses in the Arctic}

The High North has been on the Norwegian foreign policy agenda for 15 years. Much has changed over this period. What characterizes the debate in 2020 are notions of great power politics and rivalry in the north. At the same time, Arctic states claim that the region is defined by cooperation and that the Arctic states have common interests that make conflict unlikely. How can two such different perceptions of the Arctic exist simultaneously? In this contribution, we separate between three different levels of security policy in and around the High North and the Arctic. This helps clarify how the region can be characterized by both cooperation and rivalry at the same time. Cooperation and rivalry differ depending on time and place, but they are not mutually exclusive.

Keywords: Arctic $\cdot$ Russia $\cdot$ China $\cdot$ USA $\cdot$ levels of analysis 